\title{
KARANTINA WILAYAH SEBAGAI IDE PENCIPTAAN FOTO SERI TENTANG TOPICAL TRENDS COVID-19
}

\author{
Pamungkas Wahyu Setiyanto \\ Novan Jemmi Andrea \\ Agus Triyana \\ Program Studi Fotografi, Fakultas Seni Media Rekam \\ Institut Seni Indonesia Yogyakarta \\ Jalan Parangtritis Km 6.5, Sewon, Bantul, Yogyakarta \\ No. Hp.: 08122969624, E-mail: pamungkaswahyusetiyanto@gmail.com
}

\begin{abstract}
ABSTRAK
Penelitian berjudul "Karantina Wilayah Sebagai Ide Penciptaan Foto Seri Tentang Topical Trends Covid-19" merupakan sebuah penelitian berbasis penciptaan seni, dengan hasil berupa foto seri yang menggambarkan suasana karantina wilayah akibat pandemi Covid-19 di Pedukuhan Pelem Sewu, RT 08 dan RT 09, Panggungharjo, Sewon, Bantul, DI Yogyakarta. Tujuan penciptaan karya foto seri ini adalah untuk menceritakan suatu keadaan karantina wilayah di masa pandemi Covid-19 dengan segala aktivitasnya. Foto seri yang dibuat merupakan aktivitas penciptaan yang menerapkan panduan pembuatan foto yang menghasilkan rangkaian foto berisi deskripsi berdasarkan tema atau topik tertentu yang sama, yaitu situasi karantina wilayah. Melalui metode observasi, perancangan konsep, hingga pemotretan, karya foto seri yang dihasilkan menggambarkan situasi karantina wilayah, yaitu penutupan akses keluar masuk pada sebuah wilayah yang di dalamnya terdapat warga yang terinfeksi Covid-19. Hasil dari penciptaan karya foto seri ini berupa karya foto yang menggambarkan suasana serta aktivitas warga yang berlangsung selama karantina wilayah diberlakukan. Kesimpulan yang didapat dari aktivitas penelitian dengan pendekatan penciptaan karya seni ini menghasilkan pemahaman tentang keadaan dan kebiasaan warga yang baru akibat pandemi Covid-19. Kebiasaan baru tersebut di antaranya adalah aktivitas pembelajaran daring, kepedulian terhadap kesehatan dan kebersihan lingkungan, serta kepedulian sesama warga untuk saling mendukung dan melewati masa karantina.
\end{abstract}

Kata kunci: karantina wilayah, foto seri, topical trends, Covid-19, pandemi

\section{ABSTRACT}

Territorial Quarantine as an Idea of Photo Series Creation about Topical Trends of Covid-19. This research entitled 'Territorial Quarantine as an Idea of Photography Series Creation about Topical Trends of Covid-19'is an art creation-based research resulting in series of photo depicting the situation of a territorial quarantine because of the Covid-19 pandemic in the hamlets of Pelem Sewu, RT 08 and RT 09 (RT:the lowest administrative unit in the neighborhood), Panggungharjo, Sewon, Bantul, DI Yogyakarta. The aim of this photo series creation is to depict the situation of the territorial quarantine during the pandemic Covid-19 along with all of its hustle and bustle. The photo series made were the activity of creating a series of photos applying the guidance of photo making resulting in a series of photo containing descriptions based on the same particular theme or topic, that is the territorial quarantine. Using the method of observation, concept design, to photoshoot, the photo series showed the situation of the territorial quarantine, described in the barricade of the entry and exit access in a certain area inhibited by Covid-19 infected residents. The results of this photo series creation were series of photographs portraying the atmosphere in that area along with the activities of the residents during the enactment of territorial quarantine. Thus, it could be concluded that this research using an approach of artwork creation produced an insight of the situation and the new habit of those residents during the Covid-19 pandemic. Some of them were the activity of online learning, the awareness towards health and environmental hygiene, and the consciousness of the residents to support each other in getting through the quarantine period.

Keywords: territorial quarantine, photo series, topical trends, Covid-19, pandemics 


\section{PENDAHULUAN}

Sejak kali pertama diumumkan kasus pertama Covid-19 oleh Presiden Jokowi, kasus infeksi Covid-19 di Indonesia terus meningkat. Berdasarkan data dari covid19. go.id, hingga Kamis (1/10/2020) tercatat ada penambahan 4.174 kasus konfirmasi positif Covid-19 dalam 24 jam sehingga total kasus di Indonesia sebanyak 291.182 kasus. Dari total kasus tersebut, angka kesembuhan pasien mencapai 218.487 orang atau $75 \%$ dari kasus terkonfirmasi. Sementara korban meninggal dunia akibat Covid-19 sebanyak 3,7 persen, yaitu 10.856 orang dari kasus terkonfirmasi (Rizal, 2020).

Pandemi Covid-19 memengaruhi hampir semua aspek kehidupan masyarakat. Berbagai aktivitas yang biasa dilakukan oleh masyarakat, seperti bekerja, sekolah, dan kegiatan lain dihentikan sementara. Perkantoran menerapkan sistem bekerja dari rumah, dan instansi pendidikan menerapkan belajar jarak jauh secara daring dengan menggunakan teknologi informasi. Hal ini dilakukan dalam rangka untuk memutus mata rantai wabah pandemi tersebut. Masyarakat disarankan untuk tetap tinggal di rumah, melakukan pekerjaan dan pembelajaran dari rumah. Suasana sepi, jalanan lengang, semua pihak berharap agar pandemi ini segera berakhir.

Situasi anomali ini memengaruhi berbagai aspek kehidupan. Beragam cara yang dilakukan pemerintah ternyata belum terlalu efektif untuk menekan jumlah penularan infeksi Covid-19. Di antara langkah pencegahan penularan yang dilakukan oleh pemerintah pusat dan daerah adalah Pembatasan Sosial Berskala Besar (PSBB) yang bertujuan untuk meminimalisasi aktivitas masyarakat di luar rumah serta mencegah terjadinya kerumunan orang di suatu tempat. Meskipun demikian, PSBB nyatanya belum efektif untuk memutus rantai penularan Covid-19. Misalnya saja di Jakarta, yang sejak diterapkan PSBB pertama pada 10-23 April 2020, tidak menunjukkan hasil yang diharapkan. Bahkan, ibu kota negara ini harus menerapkan PSBB untuk ke sekian kalinya yang berlaku mulai 28 September hingga 11 Oktober 2020. Selain PSBB, pemerintah juga melakukan berbagai strategi lain untuk meminimalisasi penyebaran wabah atau pandemi Covid-19. Pemerintah pusat memberikan kewenangan yang disesuaikan dengan kondisi daerah masing-masing kepada pemerintah daerah untuk mengambil sikap dalam rangka mengantisipasi penyebaran pandemi Covid-19. Kewenangan status daerah dalam penanganan pandemi Covid-19 ini di antaranya dengan menetapkan status karantina wilayah. Status karantina wilayah diberlakukan untuk suatu wilayah ketika warga atau masyarakatnya terpapar Covid-19. Penetapan status karantina wilayah ini bisa ditetapkan dari pusat atau pemerintahan paling rendah, yaitu tingkat desa.

Wilayah atau daerah yang menetapkan status karantina wilayah salah satunya adalah Desa Panggungharjo, Sewon, Bantul, DI Yogyakarta. Pemerintah Desa Panggungharjo dalam rangka pencegahan mewabahnya Covid-19 menerapkan karantina wilayah di Pedukuhan Pelem Sewu, tepatnya RT 08 dan RT 09 pada Minggu, 5 April 2020. Kepala desa menetapkan status karantina wilayah terhadap dua RT tersebut setelah diketahui bahwa salah satu warga di RT tersebut terpapar Covid-19. Penetapan karantina wilayah dalam tingkatan desa ini, tentunya mengakibatkan perubahan kondisi sehari-hari warga di wilayah tersebut. Warga dua RT yang ditetapkan dalam status karantina wilayah ini tidak bisa leluasa untuk 
melakukan aktivitasnya sehari-hari. Kebijakan status katrantina wilayah ini diambil oleh kepala desa dengan harapan bahwa warga desa bisa mengupayakan agar tidak melakukan aktivitasaktvitas yang menimbulkan penyebaran wabah Covid-19 lebih luas. Warga yang menjalani karantina wilayah ini harus melaksanakan protokol kesehatan pencegahan Covid-19, monitoring kesehatan harian secara tertib, dan tidak ke luar rumah kecuali untuk hal yang penting dan mendesak. Penerapan karantina wilayah ini salah satunya dengan membatasi akses keluar masuk di sekitar kediaman warga tersebut untuk mengurangi kontak sehingga akses desa tersebut diubah menjadi satu jalur pintu masuk untuk mempermudah melakukan pengawasan. Untuk menjaga keamanan warga, jalur masuk desa tersebut dilakukan penjagaan dengan mendirikan pos penjagaan yang dilakukan oleh warga sendiri dengan dibantu oleh pemerintahan desa serta Babinsa Kecamatan Sewon, Bantul. Selain itu, untuk memenuhi kebutuhan sehari-hari warga dalam masa karantina wilayah ini pemerintahan desa membagikan sembako kepada warga sekitar agar tidak keluar untuk membeli pasokan makanan.

Situasi itu memunculkan ide untuk membuat karya yang merepresentasikan kondisi anomali yang terjadi pada masa pandemi. Karya yang dihasilkan diharapkan menjadi sebuah arsip yang dapat menjadi data atau referensi tentang berbagai hal terkait masa pandemi. Dalam penelitian ini, masa pandemi, khususnya situasi karantina wilayah menjadi sumber utama ide penciptaan karya berupa foto seri.

Foto seri yang dibuat merupakan bagian dari bentuk foto cerita yang menunjukkan atau menggambarkan suasana karantina wilayah. Situasi khusus tentang karantina wilayah merupakan topical trends sebagai latar belakang penemuan ide cerita. Foto seri yang dibuat merupakan aktivitas penciptaan yang menerapkan panduan pembuatan foto yang menghasilkan rangkaian foto berisi deskripsi berdasarkan tema atau topik tertentu yang sama, yaitu situasi karantina wilayah. Melalui metode observasi, perancangan konsep, hingga pemotretan, karya foto seri yang dihasilkan menggambarkan situasi karantina wilayah, yaitu penutupan akses keluar masuk di sebuah wilayah yang di dalamnya terdapat warga yang terinfeksi Covid-19. Selain sebagai implementasi ide, konsep, dan keterampilan fotografi penciptanya, penciptaan karya fotografi ini bertujuan untuk menawarkan sebuah karya fotografi berbentuk foto seri yang dapat menjadi arsip sejarah terkait masa pandemi Covid-19.

Penciptaan ini juga dikuatkan dengan beberapa tinjauan pustaka yang digunakan, yaitu foto seri yang dijelaskan sebagai fotofoto yang dibuat berdasarkan tema tertentu dan digunakan sebagai media penyampaian pesan atau informasi dengan gaya bercerita, deskriptif, ataupun naratif, sangat popular saat ini. Alwi (2004:6) menyebutkan bahwa foto seri adalah rangkaian foto yang jumlahnya lebih dari satu dan memiliki kesamaan tema. Ditegaskan pula oleh Wijaya (2016:27) yang menjabarkan bahwa salah satu bentuk foto cerita adalah series (seri) yang berisi rangkaian foto seragam dan memiliki muatan deksriptif dalam setiap foto. Akibatnya, susunan foto dapat ditukar tanpa mengubah isi cerita. Kesamaan tema dan kemiripan wujud visualnya menjadi kekuatan foto seri. Setiap foto yang menjadi bagian dalam sebuah seri mendeskripsikan hal spesifik terkait subjek-subjek yang ada di dalam foto.

Lebih jauh, sebagai karya seni penciptaan foto seri ini merupakan bagian dari foto jurnalistik yang dalam penciptaannya 
membutuhkan metode tertentu. Sejumlah aspek dirasa perlu dipertimbangkan untuk menguatkan muatan dari foto yang dibuat. Beberapa aspek tersebut di antaranya pola alur, bobot, dan penguatan nilai-nilai penting dalam setiap foto yang akan disampaikan kepada audien (Setiyanto \& Irwandi, 2017).

Berdasarkan penjabaran tersebut, penghadiran karya fotografi yang didasarkan pada pendekatan jurnalistik tentunya bermula dan berkaitan erat dengan kemanusiaan. Kaitan tersebut termasuk dalam hubungan pribadi manusia sebagai individu yang berhubungan dengan individu lainnya maupun dengan lingkungan sosial bahkan alam (Andrea, 2015).

Deksripsi setiap foto mengacu pada tema besar yang menjadi latar belakang foto seri itu sendiri. Masing-masing foto memiliki kekuatan visual dan cerita yang setara. Oleh karenanya, rangkaian foto seri disusun berdasarkan deskripsi saja, bukan berdasarkan alur tertentu yang salah satu foto harus menjadi pembuka dan lainnya menjadi penutup. Setiap foto bisa difungsikan baik sebagai pembuka, isi, maupun penutup. Jalinan cerita tidak akan berubah jika susunan foto berubah.

Selain foto seri, dijelaskan pula tentang topical trends sebagai salah satu cara yang bisa dilakukan untuk menemukan ide penciptaan karya foto cerita. Kobre (2008:231-232) menyebutkan beberapa aspek untuk membentuk atau membangun ide cerita, yaitu personal experience, assignment, topical trends, dan spotting trends. Topical trends merupakan aspek dalam penciptaan karya fotografi yang didasarkan pada sebuah topik yang hangat atau sedang terjadi di masyarakat pada masanya.

Berdasarkan dari yang disampaikan oleh Kobre tersebut, dalam proses implementasi atau proses penciptaan karya dalam foto cerita salah satunya dapat menggunakan aspek topical trends. Aspek ini dapat menjadi salah satu aspek untuk membentuk atau membangun ide sebuah karya foto cerita atau foto seri.

Topical trends ini biasanya berhubungan atau berasal dari sebuah topik yang sedang hangat atau sedang terjadi dan sangat menjadi perhatian semua orang pada masanya. Selain itu, topical trends ini juga bisa dilakukan dalam upaya untuk membuat sebuah karya seni fotografi yang berbasis pada pendekatan jurnalistik karena dapat dilakukan tanpa adanya penugasan khusus, artinya penciptaan karya fotografi ini dilakukan secara mandiri atas dorongan pengalaman estetik seseorang, yang kemudian dicurahkan dalam bentuk karya foto seri.

Dalam bagian topical trends, foto cerita yang dibuat biasanya menceritakan sebuah topik yang sedang hangat atau mutakhir. Karakter ini menyebabkan pembuatan foto dengan pendekatan topical trends memerlukan riset untuk menguatkan isi ceritanya.

Landasan untuk memperkuat penciptaan ini juga dilandasi oleh penciptaan terdahulu tentang foto cerita mengenai Covid-19. Salah satunya adalah karya Muhammad Adimaja, fotografer Kantor Berita Antara. Ia merupakan salah satu wartawan yang sempat meliput peristiwa yang dihadiri oleh Menteri Perhubungan Budi Karya Sumadi yang dinyatakan positif terinfeksi Covid-19. Setelah melakukan pemeriksaan di RSPI Sulianti Saroso, ia dinyatakan warga dengan status Orang Dalam Pemantauan (ODP). Kondisi tersebut mendorongnya untuk melakukan isolasi mandiri di rumahnya sesuai anjuran pemerintah dan dokter. Selama masa isolasi tersebut, ia membuat sebuah foto cerita yang menggambarkan suasana tempatnya melakukan isolasi, yang dilengkapi foto lain untuk mendampingi dan menguatkan cerita tentang isolasi dan karantina. 


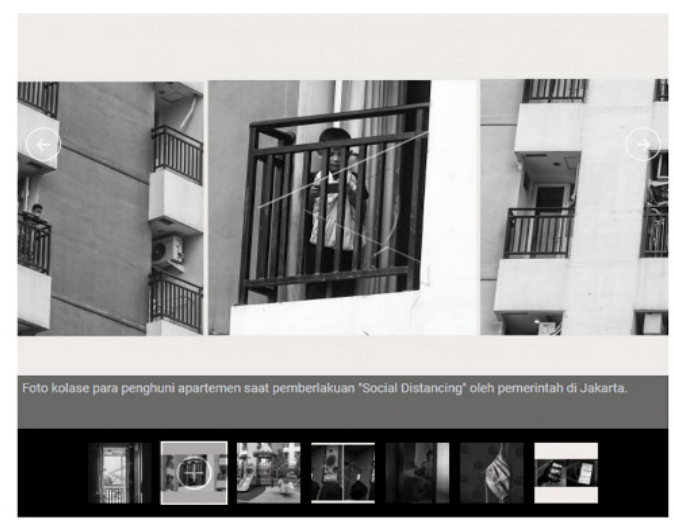

Gambar 1 Foto Cerita berjudul "Isolasi” karya Pewarta

Foto Antara Muhammad Adimaja

Sumber : https://www.antarafoto.com/foto-cerita/ v1584937834/isolasi, diakses pada 5 April 2020

\section{METODE}

Tahapan penciptaan dilakukan dengan metode kajian sumber yang terdiri dari cara riset dan observasi, visualisasi ide dan konsep yang terdiri dari teknik pemotretan dan alat dan bahan yang digunakan, serta perwujudan karya yang dimulai dari tahap seleksi awal hingga seleksi akhir.

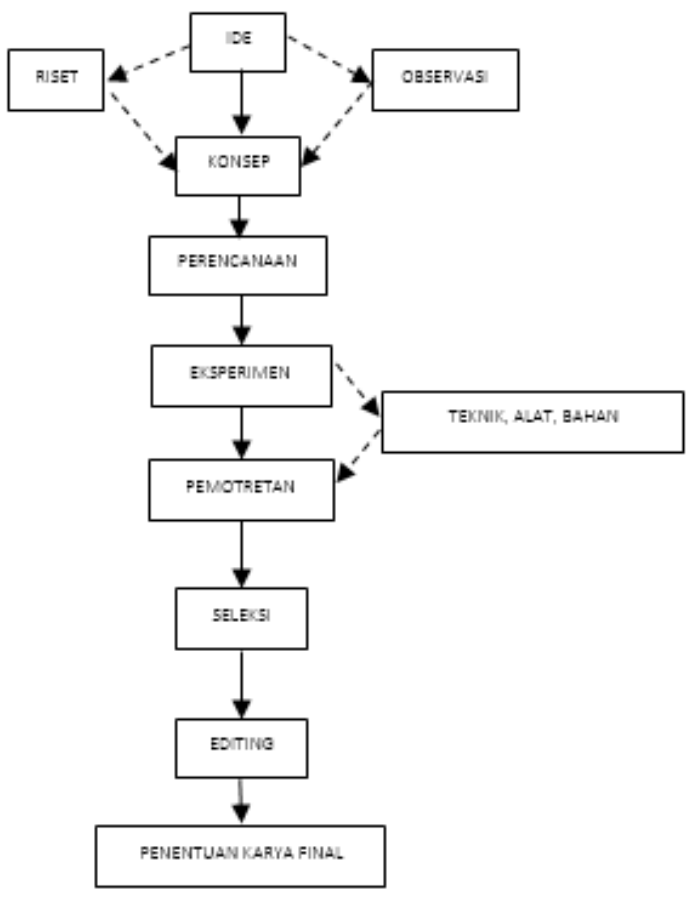

Gambar 2 Bagan Metode Penciptaan

\section{PEMBAHASAN}

Selama proses penelitian yang dilakukan hingga disusunnya laporan ini, tahapan yang sudah dilakukan di antaranya adalah pengumpulan referensi, pengumpulan data, pengelompokan dan pemilihan foto, serta editing foto sebagai materi utama penelitian. Proses dilakukan secara bertahap, tetapi dengan langkah yang efektif dan efisien. Beberapa proses atau tahapan yang dilakukan mengacu pada kesiapan data dan waktu yang disesuaikan dengan proses pemotretan sebagai langkah penyusunan materi utama penelitian.

Dari tahapan pemotretan yang dilakukan, didapatkan foto-foto tentang karantina wilayah di Karangnongko RT 09, Panggungharjo, Sewon, Bantul, Daerah Istimewa Yogyakarta. Kondisi karantina wilayah selama dua pekan di kawasan tersebut menjadi lokasi utama pemotretan. Berbagai aktivitas yang terjadi di wilayah tersebut didokumentasikan dengan pendekatan dokumenter yang merekam kejadian sesuai apa yang terjadi. Hal tersebut dipilih dengan pertimbangan agar kondisi karantina wilayah dapat ditampilkan dengan lugas dan sesuai kondisi yang terjadi.

Sesuai konsep awal, pemotretan dilakukan untuk mendapatkan foto cerita tentang peristiwa yang ada di lokasi karantina. Dari titik penutupan wilayah, yaitu portal jalan yang ditutup, lalu suasana interaksi masyarakat di lokasi karantina, detail aktivitas pemenuhan kebutuhan pangan bagi warga yang terdampak karantina, hingga aktivitas lain yang berkaitan dengan suasana bekerja dan belajar dari rumah.

Karantina wilayah sebagai cara untuk meminimalisasi penyebaran penularan Covid-19 dilakukan oleh kepala desa di Karangnongko RT 09, Panggungharjo, Sewon, Bantul, Daerah Istimewa Yogyakarta. Penetapan status karantina 
tersebut dilakukan pada hari Minggu, 5 April 2020. (http://www.panggungharjo.desa.id).

Karantina di wilayah tersebut dilakukan berdasarkan kesepakatan antara kepala desa dengan ketua RT dan tokoh masyarakat setempat. Keputusan melakukan karantina wilayah disebabkan adanya salah satu warga di wilayah tersebut yang tertular dan berstatus sebagai pasien positif Covid-19. Peristiwa tersebut menjadi ide dasar dari penelitian ini, yaitu pembuatan foto seri tentang pandemi Covid-19 yang sedang menjadi topical trends di dunia.

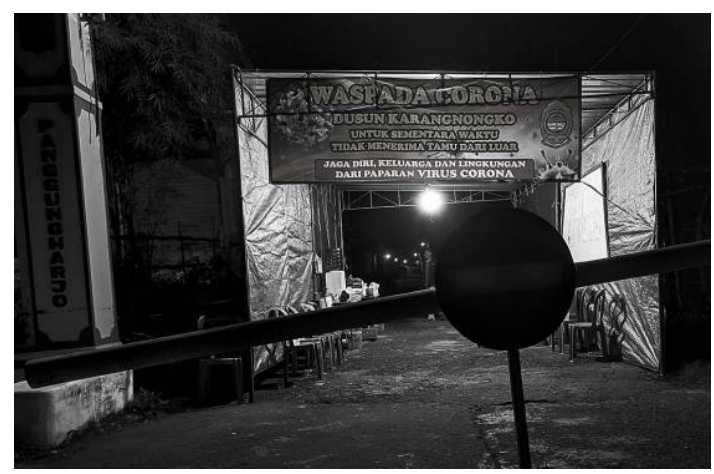

Foto 1 Satu Jalur, 2020

Foto: Pamungkas Wahyu Setiyanto

Satu Jalur. Jalan utama kampung karangnongko ditutup 24 jam dan tidak menerima tamu dari luar karena status karantina wilayah.

Karantina wilayah ditandai dengan penutupan akses keluar masuk ke dalam kampung. Penutupan atau pembatasan akses ini dilakukan untuk memastikan bahwa tidak ada interaksi antara orang dari dalam kampung dan orang dari luar kampung agar mata rantai penularan dapat diputus.

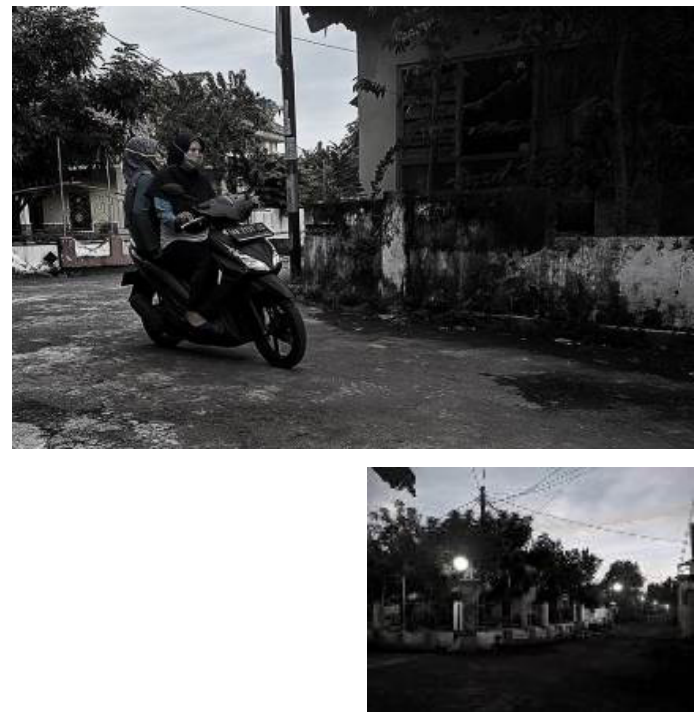

Foto 2 Lengang. 2020

Foto: Pamungkas Wahyu Setiyanto

Lengang. Warga yang beraktivitas di luar harus melakukan protokol kesehatan Covid-19. Mereka wajib menggunakan masker.

Akibat pembatasan dan penutupan akses keluar dan masuk ke wilayah kampung, suasana di dalam kampung pun menjadi lengang. Warga memilih untuk beraktivitas di dalam rumah untuk menghindari kontak fisik dengan warga lainnya.

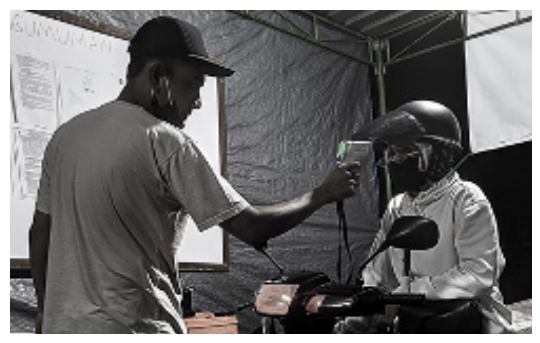

Foto 3 Wajib Cek, 2020

Foto: Pamungkas Wahyu Setiyanto

Wajib cek. Warga yang mau masuk kampung Karangnongko wajib disemprot desinfektan dan dicek suhu tubuhnya. Apabila suhu melebihi $37^{\circ} \mathrm{C}$, warga tidak diperbolehkan untuk masuk kampung.

Salah satu upaya lain untuk memastikan protokol pencegahan penularan Covid-19 adalah dengan mengecek suhu tubuh bagi setiap warga yang akan memasuki kampung. Pengecekan suhu 
tubuh menjadi prosedur wajib untuk mengetahui kondisi kesehatan seseorang yang nantinya dapat menjadi bahan pertimbangan untuk mengizinkan apakah seseorang boleh memasuki wilayah kampung atau tidak.

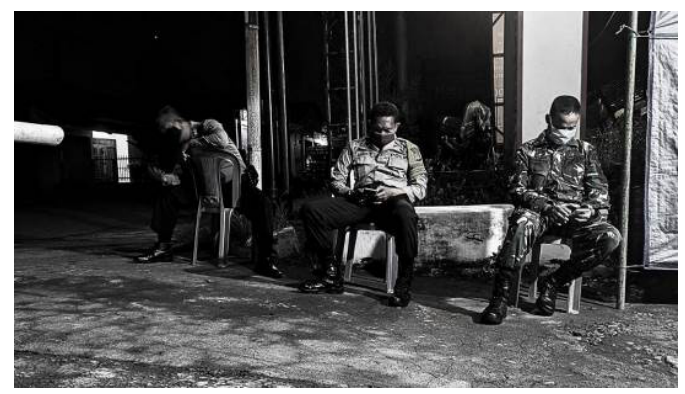

Foto 4 Babinsa, 2020

Foto: Pamungkas Wahyu Setiyanto

Babinsa. Aparat keamanan dari satuan Polri dan TNI yang berada di wilayah Kecamatan Sewon diperbantukan untuk ikut menjaga keamanan kampung Karangnongko yang sedang menjalani karantina wilayah.

Guna memastikan kondisi kampung yang dikarantina dalam keadaan yang aman, pihak kepolisian dan TNI pun berperan aktif turut menjaga keamanan lingkungan. Polisi dan TNI secara bergantian berjaga 24 jam di wilayah kampung bersama warga.
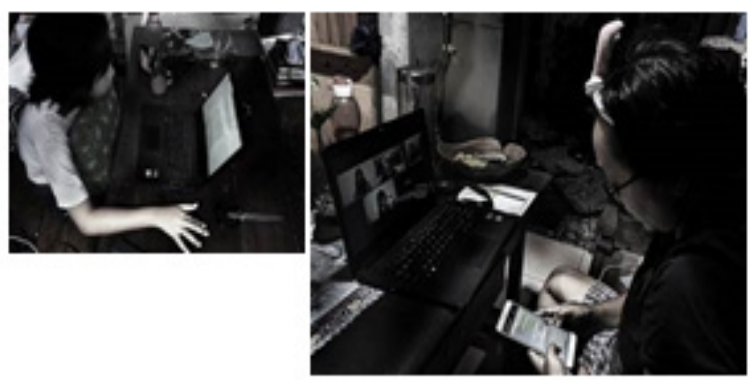

Foto 5 Semua dari Rumah. 2020

Foto: Pamungkas Wahyu Setiyanto

Semua dari Rumah. Anak-anak dan orang tua harus melakukan aktivitas baik belajar maupun bekerja dari rumah.

Akibat penutupan wilayah, aktivitas warga pun disarankan dilakukan dari rumah. Aktivitas tersebut antara lain belajar dan bekerja. Dengan memanfaatkan gawai dan teknologi informasi, anak-anak mengikuti kegiatan pembelajaran jarak jauh dari rumah, sedangkan orang tua juga melakukan pekerjaan dari rumah. Selain itu, untuk kebutuhan sehari-hari seperti belanja kebutuhan pokok juga dilakukan dengan memanfaatkan teknologi informasi.

COD. Tim belanja mengantar pesanan warga, pembayaran dilakukan ditempat

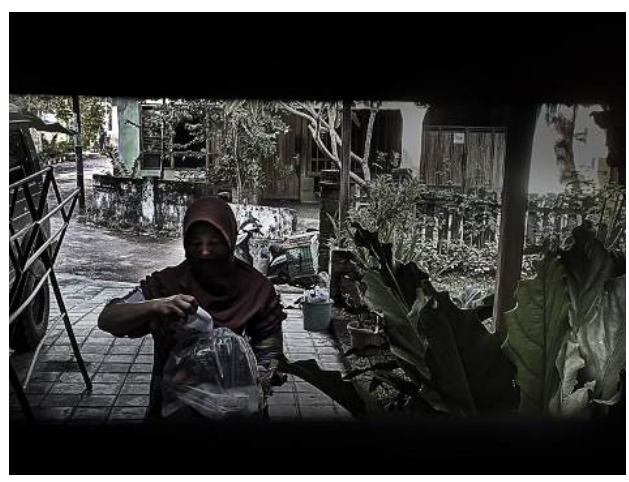

Foto 6 COD. 2020

Foto: Pamungkas Wahyu Setiyanto

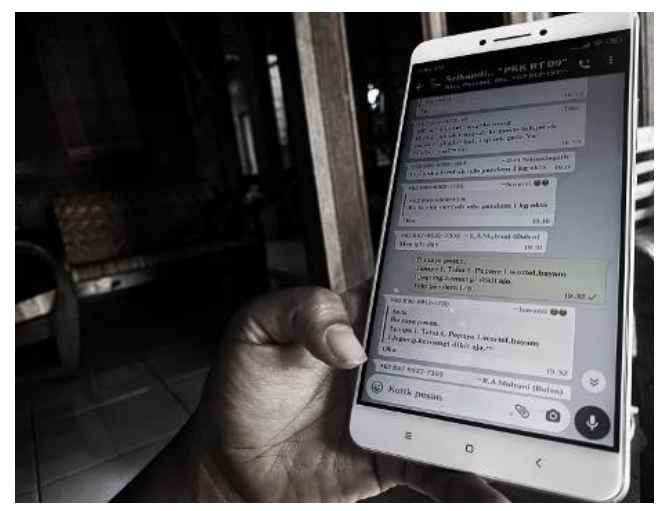

Foto 7 Online. 2020

Foto: Pamungkas Wahyu Setiyanto

Online. Karena karantina wilayah, warga pesan bumbu masak lewat online dengan fasilitas aplikasi pesan instan.

Pemanfaatan teknologi diaplikasikan di hampir semua aktivitas sehari-hari. Pemesanan bahan kebutuhan pokok dilakukan secara online/ daring yang nantinya pesanan tersebut akan diproses oleh warga lainnya yang bertindak sebagai relawan yang sekaligus akan mengantarkan pesanan tersebut ke rumah warga yang memesan. 
Di antara semua hal yang dilakukan untuk mencegah penyebaran penularan Covid-19 di kampung tersebut adalah kesadaran warga untuk menyediakan akses untuk mencuci tangan di setiap rumah. Pandemi Covid-19 membawa kebiasaan new normal, yaitu kebiasaan warga untuk selalu memakai masker dan mencuci tangan sesering mungkin.

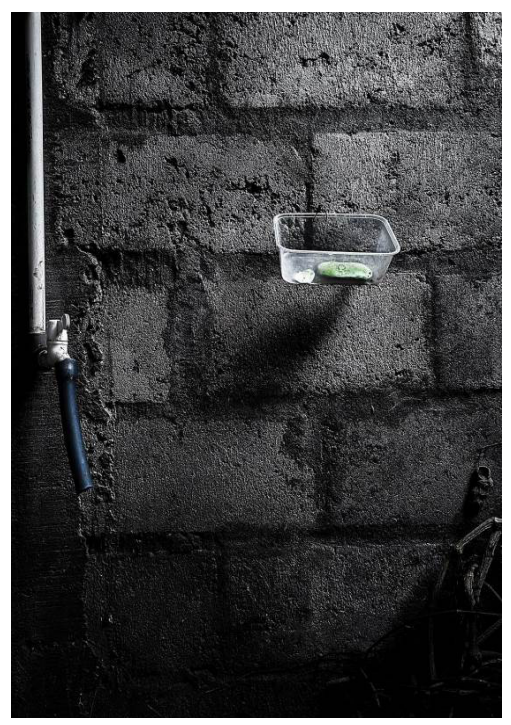

Foto 8 Wajib. 2020

Foto: Pamungkas Wahyu Setiyanto

Wajib. Setiap rumah warga pada masa karantina wilayah wajib menyediakan di luar rumah tempat cuci tangan dengan sabun dan air yang mengalir. Hal ini merupakan salah satu protokol kesehatan yang dijalani oleh warga Karangnongko yang dalam status karantina wilayah.

\section{SIMPULAN}

Penelitian dengan pendekatan penciptaan karya foto seri tentang karantina wilayah pada masa pandemi Covid-19 ini menampilkan suasana wilayah yang dikarantina. Foto-foto yang dihasilkan memiliki narasi yang mandiri dan dapat dipertukarkan urutannya tanpa memengaruhi narasi utamanya tentang karantina wilayah. Hal tersebut dikarenakan foto-foto yang dihasilkan menggambarkan situasi yang terjadi di wilayah yang dikarantina.
Aspek topical trends mengenai dampak pandemi Covid-19 dalam penciptaan ini dipandang tepat karena mampu memenuhi kebutuhan dari ide dan konsep yang ditentukan dalam penciptaan foto cerita karantina wilayah yang menjadi dampak dari pandemi ini. Dengan aspek topical trends, yaitu sebuah topik yang hangat atau sedang terjadi di masyarakat pada masanya, karya foto cerita yang diwujudkan merupakan gambaran atau cerita tentang wilayah beserta warganya yang mengalami peristiwa karantina wilayah.

Berdasarkan analisis dan penciptaan karya foto seri dengan aspek topical trends sebagai latar belakang penemuan ide cerita, tercipta karya foto seri dengan judul "Karangnongko Berdaya Kala Karantina Wilayah Covid-19”. Tentang implementasi aspek topical trends dalam menemukan ide mencipta karya fotografi ini dilakukan dengan mengambil lokasi buru foto yang ditetapkan status karantina wilayah oleh pemerintah desa adalah Kampung Karangnongko RT 09, Pelemsewu, Panggungharjo, Sewon, Bantu, Daerah Istimewa Yogyakarta. Hasil buru foto yang dilatarbelakangi ide penciptaan karya dengan aspek topical trends, kemudian ditata dan diselaraskan dalam bentuk foto seri yang merupakan bagian dari bentuk foto cerita. Karakter foto seri yang dapat diamati dalam penciptaan ini adalah fleksibilitas susunan foto yang dapat diubah-ubah tanpa mengubah isi narasi foto yang disampaikan mengenai kondisi dalam sebuah kampung yang ditutup akibat karantina wilayah. Pertukaran susunan tersebut dapat dilakukan karena hubungan masing-masing foto bukan hubungan kronologis.

Untuk mendapatkan hasil yang maksimal dalam proses penciptaan karya fotografi dengan bentuk foto seri, ada beberapa hal yang harus diperhatikan, antara lain: 
1. Kepekaan dalam pengamatan objek yang menjadi tujuan buru foto. Fotografer harus peka dan jeli dalam menangkap momen agar tidak terlewat momen yang mendukung dalam penyampaian cerita dalam bentuk foto seri.

2. Dalam pemilihan aspek topical trends sebagai dasar dalam penciptaan karya foto cerita penghimpunan informasi awal tentang objek pemotretan mutlak diperlukan agar fotografer dapat menentukan alur cerita yang ingin dibangun.

3. Persiapan dalam buru foto menyangkut alat fotografi seperti cek baterai,vkapasitas kartu memori, dan variasi lensa yang digunakan sangat memengaruhi hasil dalam buru foto.

4. Kemampuan mengedit dan menata untuk penyelarasan cerita juga penting untuk dikuasai, dalam rangka untuk membentuk perwujudan karya.

\section{UCAPAN TERIMA KASIH}

Ucapan terima kasih kepada Lembaga Pengabdian dan Penelitian Kepada Masyarakat (LPPM) Institut Seni Indonesia (ISI) Yogyakarta yang telah mendukung melalui program Penelitian Dosen Terapan.

\section{KEPUSTAKAAN}

Alwi, A. (2004). Foto Jurnalistik, Metode Memotret dan Mengirim Foto ke Media Massa. Jakarta: Bumi Aksara.

Andrea, N. J. (2015). Estetika Fotografi Jurnalistik dalam Kaitan Nilai Kebaikan dan Kebenaran, Olah Rasa, dan Sinestesia. Rekam: Jurnal Fotografi, Televisi, Animasi, 11(2), 94. https://doi.org/https:// doi.org/10.24821/rekam.v11i2.1296

Kobre, K. (2008). Photojournalism: The Professional Approach - 6th (6th ed.). Focal Press.

Rizal, J. G. (2020). Melihat Peningkatan Kasus Corona di Indonesia Selama 7 Bulan Pandemi. Kompas.Com. https://www.kompas.com/tren/ $\mathrm{read} / 2020 / 10 / 02 / 140000265 /$ melihatpeningkatan-kasus-corona-di-indonesiaselama-7-bulan-pandemi?page $=$ all

Setiyanto, P. W., \& Irwandi. (2017). Foto Dokumenter Bengkel Andong Mbah Musiran: Penerapan dan Tinjauan Metode Edfat dalam Penciptaan Karya Fotografi. Rekam: Jurnal Fotografi, Televisi, Animasi, 13(1), 30. https://doi.org/https:// doi.org/10.24821/rekam.v13i1.1580

Wijaya, T. (2016). Photo Story Handbook Panduan Membuat Foto Cerita. Jakarta: Gramedia Pustaka Utama.

\section{LAMAN PUSTAKA}

http://www.panggungharjo.desa.id/pemdespanggungharjo-terapkan-karantina-wilayahpada-pedukuhan-pelem-sewu/ 
